\title{
Sustainable development of network interaction between business structures and local governments
}

\author{
Anna Schmeleva ${ }^{1, *}$ \\ ${ }^{1}$ Plekhanov Russian University of Economics, Moscow, Russia
}

\begin{abstract}
There is a long-term dependence of most regions on federal budget subsidies in Russia. The policy of artificial financial equalization of the regions can create a dependent mood in weak regions and deprive the incentive to develop strong regions. In the Covid-19 era, the regions of the Russian Federation must find alternative sources of financing for their projects, including entrepreneurial ones, for example, through "people's financing" and activation of territorial development based on the crowdfunding mechanism. The main purpose of the article is to consider the prospect of using crowdfunding as a sector of the distributed economy as an alternative financial tool to develop network interaction between business structures and self-government bodies in Russia. According to the authors, the development of such practices is due to several factors: the mixed results of applying self-taxation practices in the regions of Russia; in some cases, there is opposition to this mechanism by the population; the introduction in 2020 of a regulator of crowdfunding platforms; the growing involvement of citizens in various IT platforms, including investment. Entering into this project financing scheme for both individuals, business entities, and local governments allows optimizing the economic potential of all participants in this network, and obtaining a synergistic effect from combining their resources.
\end{abstract}

\section{Introduction}

In economics, a network is a way of regulating the interdependence of participants in a single technological process, based on a cooperative "game" and special relationships. Combining the efforts of management bodies and business entities in a certain territory gives significant advantages in competition and production and market processes rationalization. Such a combination of efforts has proved quite effective in terms of implementing programs for the economic development of regions, and sometimes even national systems in some countries [1,2,3]. A four-dimensional construct, including network orientation, network building, network maintenance, and network coordination, aimed at improving the development efficiency of start-up entrepreneurs, is proposed in the work by scientists from China [4].

\footnotetext{
*Corresponding author: schmelevaanna@mail.ru
} 
A number of researchers [5] talk about the transition of the "entrepreneurial network" concept to the concept of an entrepreneurial ecosystem. However, the understanding of how entrepreneurial ecosystems evolve over time is still limited, and in some cases the evolution of entrepreneurial ecosystems is defined as a chaotic process [6]. American scientists believe that entrepreneurial ecosystems are heterogeneous in terms of the key characteristic of the system level - its sustainability. They argue that entrepreneurial ecosystems are distinguished both by the diversity of participants, businesses, business models and support organizations, and by their consistency with shared values and activities. The relationship between the ecosystems` diversity and coherence, in turn, ensures their sustainability [7].

Entrepreneurial ecosystems represent an active and growing field of research. Recognized as one of the factors contributing to regional competitiveness by stimulating economic growth and encouraging innovation, interest in this concept spans a variety of disciplines. An international team of scientists [8] conducted a bibliographic analysis of the existing literature in this field for the period of 1995-2019. The scientists reviewed the origin of the entrepreneurial ecosystems concept in the literature, gave an idea of the key concepts that appeared in research over the past 25 years.

Spanish researchers [9] conducted an analysis of 911 Spanish innovative startups and found that the effect of agency communication within the network reduced various obstacles for startups. Identifying the importance of the various agents of the entrepreneurial ecosystem in reducing innovation barriers can help startups and policy makers identify the key agents and resources needed to support startup innovation and prioritize accordingly. The paper [10] deals with assessing the impact of entrepreneurial ecosystems on the development of new and innovative companies in specific territories. It suggests the classification of local entrepreneurial ecosystems into such types as: Active self-propelled, Indulged and Passive self-absorbed. The study [11] also points out that conditions in the entrepreneurial ecosystem can help a sustainable startup, with successful entrepreneurs becoming leaders (beacons) in the ecosystem and thereby helping to shape the cultural, social, and material conditions in the ecosystem. Entrepreneurial ecosystems are most widely explored in such areas of activity as tourism $[12,13,14]$ and hospitality [15]. It is worth noting that there are works aimed at analyzing the impact of digital technologies on the entrepreneurial networks and ecosystems development. An example is an article [16] where the authors define the digital entrepreneurship ecosystem and identify its four elements: digital actors (who), digital activities (what), digital motivations (why), and digital organization (how).

It is obvious that property relations play a significant role in networking, but business structures can be grouped without relying on these connections, thus forming an entrepreneurial network that combines elements of the market and a certain coordination of actions. Cooperation and information relations come to the fore in it, and property relations can be present in the form of equity participation. The business networks creation is associated with the integration behavior of the business system subjects. One of the most striking examples of such a network interaction of business structures in Russia is the use of crowdfunding IT platforms in their activities. This interaction became possible only in the conditions of active development of the distributed use economy. In this article, we consider the prospect of using crowdfunding in Russia as a sector of the distributed economy as an alternative financial tool for developing network interaction between business structures and self-government bodies. The relevance of this proposal is primarily due to the fact that in the era of Covid-19, the regions of the Russian Federation should find alternative sources of financing for their projects, including entrepreneurial ones, for example, through "people`s financing" and the activation of territorial development based on the crowdfunding mechanism. 


\section{Materials and methods}

Both practical and theoretical methods were used in this article. The practical methods include the collection of information on financing mechanisms for local issues applied in the Russian Federation. The primary sources of information were: legal acts regulating Russian citizens' self-employment; information from official websites of the Russian Government and regional authorities. Theoretical methods of generalization and analysis of practical information also contributed in the creation of the following schemes proposed in the article: scheme of financial participation of individuals and legal entities in the territorial development of the country based on the crowdfunding mechanism and operational leasing scheme based on the use of territorial crowdfunding investment platforms.

\section{Results}

The lack of financial resources to develop Russian regions, including their entrepreneurial initiatives, is one of the main problems of territorial administration.

An alternative way to co-finance local expenses is to use self-taxation mechanisms of citizens, the practice of which has been developed in our country for a long time. In the Decree "On the self-taxation of the population to satisfy local public needs" of 1924, it is noted that the self-taxation of the population was established to satisfy all kinds of local public needs (the maintenance of educational, medical, social welfare institutions, as well as the satisfaction of the needs of local improvement, etc.) and was allowed solely on the basis of a voluntary agreement of citizens [17]. It should be noted that initially there were no legislatively established forms of control over the expenditure of these funds. Subsequently, in the period 1927-1930, documents were adopted [18] introducing mandatory self-taxation and monitoring the use of funds, as well as providing for control over the payment of funds by the population. The order of use became legislatively regulated; proceeds were directed to the development of local social institutions. Under the current legislation and in accordance with federal law No. 131-FZ "On General Principles of the Organization of Local SelfGovernment in the Russian Federation" [19], self-taxation means one-off payments by citizens made to resolve specific issues of local importance. The decision to introduce selftaxation and the use of these funds is made based on the results of a local referendum or at a gathering of citizens. The size of payments, with a few exceptions, was set the same for all residents of a municipal entity, with the exception of certain categories of citizens, the number of which cannot exceed 30 percent of the total number of residents of the municipal entity. At present, the principle of voluntary payment of these payments is valid, which is also confirmed by court decisions.

The federal law No. 131-FZ regulates the concept of "territorial public self-government", which refers to the self-organization of citizens at their place of residence on the territory of a settlement, the inner city territory of a city of federal significance, the municipal district, urban district, intracity district, as well as settlements located on inter-settlement territory (or part of their territory) for independent implementation under their own responsibility of their own initiatives on issues of local importance. Territorial public self-government is carried out directly by the population through holding meetings and conferences of citizens, as well as through the creation of bodies of the territorial public self-governments (TPSG). In accordance with its charter, a territorial public self-government may be a legal entity and is subject to state registration in the legal form of a non-profit organization. Now there are about 30 thousand of such organizations in Russia, and the regions have left the capitals far behind in terms of self-organization; almost as many territorial public self-government bodies have been created in rural areas as in cities. However, less than ten per cents of the territorial public self-government bodies have the legal entity status. The majority is registered in the form of 
a public organization that does not give enough authority for active interaction with local governments.

In 2018, the Russian Federation began the implementation of the Initiative Budgeting (IB) Development Program, the activities of which were included in the state program "Public Finance Management and Regulation of Financial Markets". An important component of information security is the possibility of participation for a wide range of citizens in putting forward ideas, discussing and choosing projects, various forms of voting and competitive selection of projects. As a rule, this is ensured through various intramural and extramural mechanisms provided for at different stages of the practice; statistics on citizen participation in such procedures are not systematic. In a number of practices, the need for counting participants in procedures at different stages is regulated in normative legal acts, as it is a way of confirming the participation of citizens.

Current practice of applying self-taxation mechanisms of citizens is rather ambiguous. Measures to stimulate self-taxation undertaken in the constituent entities of the Russian Federation lead to very different results. In some regions, the experience of developing selftaxation was recognized as successful, in others the introduction of this mechanism did not lead to the expected results and the collected funds of the population did not exceed the costs of holding a referendum, and thirdly, opposition to the implemented practices by the population remains. Obviously, the most successful is the experience of territories where cofinancing from the regional budget is used to activate self-taxation. Since 2015, the development of initiative budgeting practices in the constituent entities of the Russian Federation has been supported as part of the direction to increase the transparency of public and municipal finance management. The development of proactive budgeting practices is included in the number of tasks to be addressed within the framework of the implementation of the "Concept for improving the efficiency of budget expenditures in 2019-2024" approved by the Government of the Russian Federation dated January 31, 2019 No. 117 - r. [20] These approaches are implemented at the federal level by including civil participation practices in the number of measures provided for by the state program of the Russian Federation "Management of public finances and regulation of financial markets". The indicators of subprogram 1 "Ensuring the Long-Term Sustainability of the Federal Budget and Improving the Effectiveness of Public Finance Management" include the indicator 1.4 "The number of subjects of the Russian Federation that approved, as part of regulatory legal acts, programs (measures) on the implementation of proactive budgeting in their territories"; their number should almost double (2018 - 33 constituent entities of the Russian Federation, 2024 - 62 constituent entities of the Russian Federation) for six years of application of the program [21]. Thus, today in the Russian Federation the following scheme of financial participation of citizens in the development of certain territories is dictated by law (Figure 1).

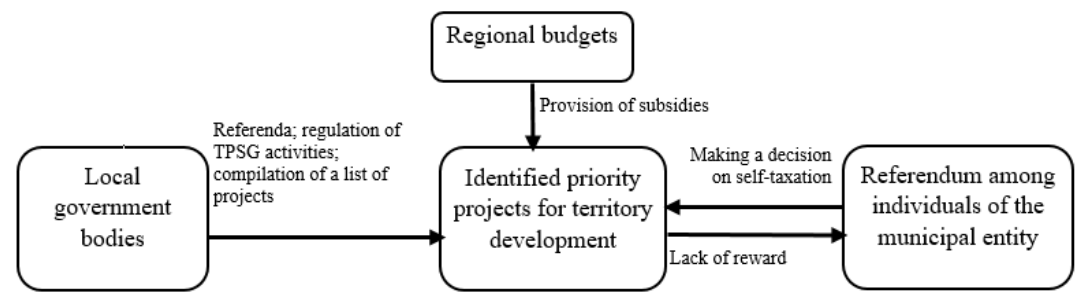

Fig. 1. Scheme of financial participation of citizens in the territorial development based on the selftaxation mechanism (own research).

However, this participation scheme can be characterized by a number of disadvantages: the need for a referendum in the municipal entity to address self-taxation for a specific project; participation in the referendum is provided only for individuals residing in the given 
territory; the lack of financial rewards for citizens from a project for the implementation of which self-taxation funds have been allocated.

There are many problematic issues for the solution of which it is possible to use completely different approaches, each of which can have a positive effect. We are proposing to look at the problem of the Russian regions development by providing network interaction of business structures and local governments based on crowdfunding IT platforms taking into account the sharing economy actively developing in the country.

Sharing economy is a phenomenon when new business models appear that are defined as technologically mediated, facilitating access to underutilized goods or services and potentially reducing net consumption [22]. Despite the fact that the term "sharing economy" was first mentioned back in 2010 in the work of Botsman R. and Rogers R. [23] and it is not uncommon as an object of study of economic science, there is no generally accepted definition of this concept until now.

One of the distinguishing characteristics of a sharing economy is the use of technologies (digital platforms and mobile applications) and lease relations (consumers do not buy goods, but borrow them for a while). Platforms of the sharing economy transform traditional systems of production and consumption in cities around the world. While the sharing economy can be aimed at increasing the sustainability of various economic systems, its actual economic, social and environmental effects remain poorly understood. In the era of Covid-19, climatic and economic crises, and growing uncertainty, including the territorial development of regions, it is becoming increasingly important to promote more sustainable and promising forms of joint (distributed) use of various resources, goods, and services. Ways to capitalize on the strengths of a sharing economy despite a significant number of both Russian and foreign publications are still poorly understood, many of them are aimed at developing theoretical aspects of this issue. Moreover, at the moment it is extremely important to study the roles, prospects and effects of both resource owners, users (individuals and businesses), enterprises and local governments, including in light of the development of territories, and the interaction platforms themselves, including in Russia.

An interesting study, "The Sharing Economy in Russia 2019”, was published by the TIAR Centre and the Russian Association of Electronic Communications (RAEC), where they estimated the volume of the sharing economy in Russia. The five leaders of the Russian sharing market in 2019 did not change compared to 2018, while car sharing was able to outperform carpooling in terms of transaction volume. The top 5 sharing sectors make the main contribution to the volume and growth of the sharing economy $(98.7 \%)$ : $\mathrm{C} 2 \mathrm{C}$ sales, services of private individuals-freelancers, car sharing, carpooling and short-term P2P rental of residential premises, the growth rate of each of the leading industries ranges from $30 \%$ to $59 \%$.

However, despite the active development of sharing in Russia, the crowdfunding segment was not deservedly forgotten by consumers. The crowdfinancing market is developing very actively around the world, increasing its momentum. It is an alternative to bank lending and one of the ways to invest.

The Alternative Lending report 2020 indicates that in 2019 the global market for alternative loans amounted to $\$ 267.1$ billion. Comparing the US, China and Europe, the size of the Chinese alternative lending market with a volume of $\$ 222.5$ billion is astonishing, China accounted for $83 \%$ of the global market in 2019 [24]. As for Russia, two sources of market appreciation are curious. The first of them is the previously mentioned report of the TIAR Centre and RAEC "Sharing economy in Russia 2019", according to which the crowdfunding market stagnates: in contrast to other sectors of the sharing economy, its growth in 2019 was $8 \%$. Russian crowdfunding venues remain places for raising funds mainly for cultural and social projects. It is worth noting that in this report, the authors do not refer crowdlending and crowdinvesting to the sharing economy, where individuals, small 
and medium-sized enterprises invest free money in business projects in order to make a profit, and assess crowdfunding as a collection of pre-orders and donations. However, they note that P2B crowdlending may become the driver of crowdfinancing in 2020 on the back of the adoption of the federal law "On attracting investments using investment platforms", entering new platforms on the market and revitalizing existing ones. The fact that the situation on the crowdfunding market isn't encouraging was also confirmed by experts of the Central Bank. According to their estimates, in the first nine months of 2019, the crowdfinancing market amounted to 5.2 billion roubles: a decrease was of almost $42 \%$. In b2b lending, the amount of borrowed funds decreased by $80.5 \%$ to 860 million roubles ( 4.4 billion roubles in 2018); the $\mathrm{p} 2 \mathrm{p}$ lending volume decreased by $70 \%$ from 268 million to 80.6 million roubles. The segment of p2b-lending increased from 4 billion roubles in 2018 to 4.1 billion roubles in 2019; the Rewards segment increased to 132 million roubles (129 million roubles in 2018).

On January 1, 2020, the Federal Law dated August 2, 2019 No. 259-FZ "On attracting investments using investment platforms and amending certain legislative acts of the Russian Federation" [25], entered into force in the Russian Federation and also called the "crowdfunding law". According to the law, the movement of non-cash funds in the form of investments occurs within the framework of special investment platforms on the Internet on the basis of relevant agreements. Investing with the use of the investment platform can be carried out in the following ways: by providing loans; by acquiring equity securities placed using the investment platform, with the exception of securities of credit institutions, noncredit financial institutions, as well as structural bonds and securities intended for qualified investors; by acquiring utilitarian digital rights. The classic crowdfunding financing scheme is presented in Figure 2.

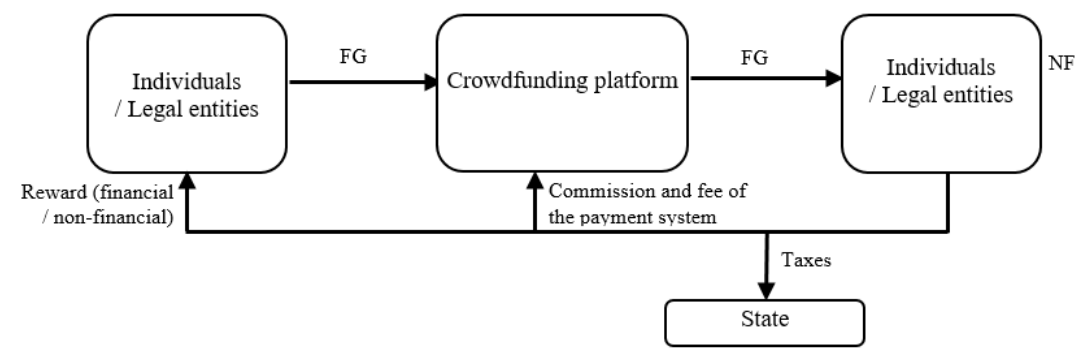

FG - financial goal, roubles; NF - the necessary funds for the implementation of the project, roubles

Fig. 2. Organization of crowdfunding financing.

Thus, it is necessary to collect such an amount of funds on a crowdfunding platform that, after the deduction from it of a crowdfunding platform commission, a payment system fee and tax, the amount of funds would remain, which are necessary directly for the implementation of the project. Crowdfunding business models can be divided into financial and non-financial. The practice of the investment platform activity in Russia indicates that the non-financial crowdfunding models have gained the most and predominant development; however, $\mathrm{P} 2 \mathrm{~B}$ and $\mathrm{B} 2 \mathrm{~B}$ crowdlending becomes necessary for the active growth of crowdfunding transactions and from the perspective of territorial development; it is the model designed for the activation of the crowdlending segment for lending to legal entities.

Taking into account the previously mentioned scheme of the citizens' financial participation in the territorial development of the country based on the self-taxation mechanism, an alternative scheme of participation of not only citizens, but also legal entities in the regional development projects implementation is proposed (Figure 3). 


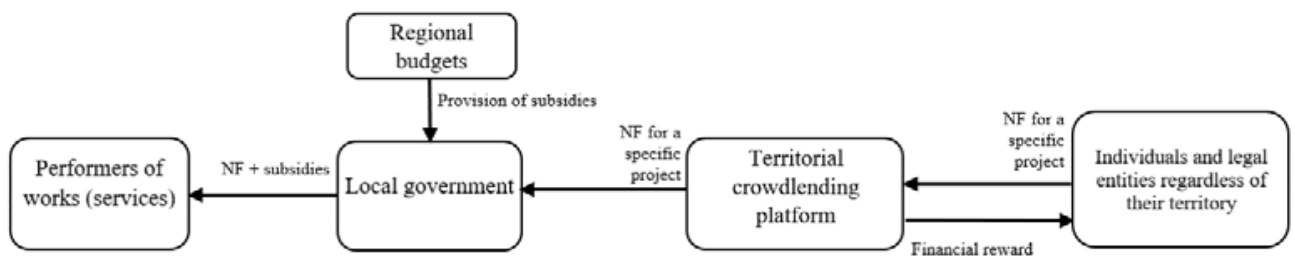

FG - financial goal, roubles; NF - the necessary funds for the implementation of the project, roubles.

Fig. 3. Scheme of financial participation of individuals and legal entities in the territorial development of the country based on the crowdfunding mechanism (own research).

The proposed financing scheme has several advantages in comparison with the currently used: participation in the financing of both individuals and legal entities; the opportunity to participate, regardless of the territory of residence or activity; there is no need for a referendum to decide on self-taxation; the possibility of obtaining financial rewards for investing in the project.

\section{Discussion}

Thus, the territorial-oriented crowdlending platforms will be the alternative investment resource used in the traditional scheme of operational leasing of equipment. It would be the operating leasing, since at the end of the contract the property is returned to the lessor, and financially becomes the property of the lessee. That is, it would be possible to use the resource without transferring ownership of it, which is a hallmark of sharing. The main source for funding leasing transactions in the Russian Federation remains bank loans, which share in the financed funds has been at least $60 \%$ over the past four years. This makes it possible to use crowdfunding (P2B segment and B2B-crowdlending) as an alternative source of investment for territorial development projects.

\section{Conclusion}

The proposed project financing scheme is aimed at developing network interaction between individuals and legal entities interested in implementing certain regional business and social projects and local governments based on crowdfunding IT platforms. Development practices on the territories of the Russian Federation, especially hard-to-reach and remote ones, are often associated with the need to purchase expensive equipment. In this case, our proposed scheme can be integrated into the operating leasing scheme, where the local government will act as the customer, and individuals and legal entities interested in developing transport accessibility of specific territories will act as investors.

\section{Acknowledgments}

Prepared as part of the state assignment of the Ministry of Science and Higher Education No. FSSW-2020-0009 "Development of a methodology for managing the competitiveness of enterprises in the field of commodity circulation in the digital economy". 


\section{References}

1. K. Jha Srivardhini, IIMB Management Review 30(2), 179-188 (2018) https://doi.org/10.1016/j.iimb.2018.04.002

2. S. Sarma, S.A. Sunny, Business Horizons 60(6), 843-853 (2017) https://doi.org/10.1016/j.bushor.2017.07.010

3. F. Rosen, P. Olsson, Marine Policy 38, 195-204 (2013) https://doi.org/10.1016/j.marpol.2012.05.036

4. Rui Shu, Shenggang Ren, Yi Zheng, Journal of Business Research 85, 197-208 (2018) https://doi.org/10.1016/j.jbusres.2017.12.048

5. F.J. van Rijnsoever, Research Policy 49(1), 103884 https://doi.org/10.1016/j.respol.2019.103884

6. T. Haarhaus, G. Strunk, A. Liening, Journal of Business Venturing Insights 14, e00194 (2020) https://doi.org/10.1016/j.jbvi.2020.e00194

7. P.T. Roundy, B.K. Brockman, M. Bradshaw, Journal of Business Venturing Insights 8, 99-104 (2017) https://doi.org/10.1016/j.jbvi.2017.08.002

8. J. Robertson, L. Pitt, C. Ferreira, Socio-Economic Planning Sciences 72, 100862 (2020) https://doi.org/10.1016/j.seps.2020.100862

9. Franco-Leal Noelia, Diaz-Carrion Rosalia, Journal of Business Venturing Insights 14, e00192 (2020) https://doi.org/10.1016/j.jbvi.2020.e00192

10. P. Muñoz, E. Kibler, V. Mandakovic, J. Ernesto Amorós, Research Policy $\mathbf{1 0 4 0 6 5}$ (2020) https://doi.org/10.1016/j.respol.2020.104065

11. S. Tiba, F.J. van Rijnsoever, M.P. Hekkert, Journal of Cleaner Production 264, 121616 (2020) https://doi.org/10.1016/j.jclepro.2020.121616

12. P.A. Milwood, A. Maxwell, Journal of Hospitality and Tourism Management 44, 243252 (2020) https://doi.org/10.1016/j.jhtm.2020.06.008

13. C. Cunha, E. Kastenholz, M. João Carneiro, Journal of Hospitality and Tourism Management 44, 215-226 (2020) https://doi.org/10.1016/j.jhtm.2020.06.007

14. S. Eichelberger, M. Peters, B. Pikkemaat, Chung-Shing Chan, Journal of Hospitality and Tourism Management 45, 319-329 (2020) https://doi.org/10.1016/j.jhtm.2020.06.011

15. B. Fabian Bichler, A. Kallmuenzer, M. Peters, Journal of Hospitality and Tourism Management 44, 152-161 (2020) https://doi.org/10.1016/j.jhtm.2020.06.009

16. G. Elia, A. Margherita, G. Passiante, Technological Forecasting and Social Change 150, 119791 (2020) https://doi.org/10.1016/j.techfore.2019.119791

17. On the self-assessment of the population to meet local public needs. Resolution of the Central Executive Committee of the USSR, Council of People's Commissars of the USSR of August 29 (1924) http://www.libussr.ru/doc_ussr/ussr_2146.htm

18. About the self-taxation of the population. Resolution of the Central Executive Committee and the Council of People's Commissars dd. August 16 (1930) http://istmat.info/node/50020

19. Federal Law $d d$. $06.10 .2003 \quad N \quad$ 131-FZ http://www.consultant.ru/document/cons_doc_LAW_44571/

20. The concept of improving the efficiency of budget expenditures in 2019-2014. Approved by order of the Government of the Russian Federation dd. January 31, 2019 No. 117-r, http://static.government.ru/media/files/oPbFFY1nPoRrQGx7Q7tfZrV5JGTUuTOR.pdf 
21. The state program of the Russian Federation "Management of public finances and regulation of financial markets." Approved by Decree of the Government of the Russian Federation April 15, $2014 \quad$ No. 320, https://www.minfin.ru/common/upload/library/2020/04/main/N_320.pdf

22. S. Kane Curtis, O. Mont, Journal of Cleaner Production 266, 121519 (2020) https://www.sciencedirect.com/science/article/pii/S0959652620315663

23. R. Botsman, R. Rogers, What's Mine Is Yours: The Rise of Collaborative Consumption (Harper Business, 2010) https://hbr.org/2010/10/beyond-zipcar-collaborativeconsumption

24. Alternative Lending report 2020. Statista Digital Market Outlook, https://www.statista.com/study/50625/fintech-report-alternative-lending/

25. Federal Law dd. August 2, $2019 \quad$ No 259-FZ, http://www.consultant.ru/cons/cgi/online.cgi ? req $=$ doc \& base $=$ LAW \& n $=330652$ $\&$ fld $=134 \&$ dst $=1000000001.0 \&$ rnd $=0.7024629357880219$ \# 0026366072501536886 